\title{
El clero en la España del siglo XVIII. Balance historiográfico y perspectivas
}

The clergy in the Spain of the eighteenth century. Historiographical balance and perspectives

Maximiliano Barrio Gozalo Universidad de Valladolid 


\section{RESUMEN}

Después de decir unas palabras sobre la renovación que se llevó a cabo en la historia eclesiástica española de la segunda mitad del siglo xx, trato de ofrecer un balance historiográfico sobre los avances que se han producido y lo mucho se ha publicado en las últimas décadas sobre el clero secular y el regular, para concluir con unas breves indicaciones sobre las perspectivas de investigación.

Palabras clave

Siglo XVIII, Historia de la Iglesia, Clero español.

Abstract

After saying a few words about the renewal that took place in the Spanish ecclesiastical history of the second half of the twentieth century, he tried to offer a historiographical account of the progress that has been made and much has been published in the last decades about The secular clergy and the regular clergy, to conclude with a brief indication of the research prospects.

KeY WoRDS

18th century, Church history, Spanish clergy.

Recibido: 25 de junio de 2017. Aceptado: 15 de julio de 2017. 
Aspectos generales

Hace más de dos siglos y medio un erudito español se lamentaba de que no hubiera una historia crítica de la Iglesia española, tanto para conservar las noticias de su pasado, como porque las cosas eclesiásticas merecían una atención especial por referirse a un fin superior ${ }^{1}$. Cuando monseñor Clemente de Aróstegui, auditor de la Rota romana, decía esto a mediados del siglo XVIII, la sacralización o, mejor, la confesionalización de la sociedad era casi total, sin ningún resquicio para la laicidad. Hoy, cuando la secularización y el secularismo imperan por doquier, ha cambiado la mentalidad, pero para los interesados por el pasado histórico, sigue siendo válida la afirmación de que la Iglesia tuvo gran importancia en la España del Antiguo Régimen, no solo como soporte esencial de la vida religiosa sino también como uno de los principales componentes de las estructuras socio-económicas e ideológicas de la sociedad. Esto hace que su estudio rebase los límites de la simple historia eclesiástico-religiosa e interese también a la historia económico-social y de las mentalidades.

A pesar de la importante labor realizada por los historiadores del pasado, que enriquecieron el conocimiento de la Iglesia española con sus estudios, la información que aportan se limita, en la mayoría de los casos, a dar noticia de la fundación de diferentes instituciones eclesiásticas (iglesias, conventos, hospitales, obras pías o cofradías), a ofrecer algunas pinceladas sobre la vida de los obispos que rigen la diócesis y a relatar ciertos fenómenos que hoy englobaríamos bajo el término de religiosidad popular². Pues, como decía Domínguez Ortiz en 1970, las fuentes para el estudio del clero «son variadísimas, la bibliografía inmensa, pero las obras realmente útiles muy escasas». No hay una Historia de

1 Alfonso Clemente de Aróstegui, De historia hispaniensis excolenda, Roma, 1747.

2 Todavía en el siglo XIX encontramos bastantes publicaciones de historia eclesiástica que se centran prioritariamente en los consabidos temas de obispos y conventos, como los dos pilares que sostienen la institución, y se puede observar en la obra de Vicente de la FuEnte, Historia eclesiástica de España, Barcelona, Imprenta de Pablo Riera, 1855-1859, 4 vols., y Madrid, Compañía de Impresores, 1873-1875, 6 vols. (2. edición corregida y aumentada). Más información en José AndRÉs GALLEgo (ed.), La historia de la Iglesia en España y el mundo hispánico, Murcia, Universidad Católica de San Antonio, 2001. En concreto en las colaboraciones de José AndRés GaLLEgo: «El nacimiento de la historiografía religiosa...», págs. 9-22, y «El siglo XVIII y el tránsito al XIX...», págs. 225-261. 
la Iglesia que resista la crítica, ni un Diccionario de Historia eclesiástica. En cambio son multitud los estudios de tipo localista y biográfico: episcopologios o crónicas monásticas, pero con ausencia de crítica y casi siempre con tendencia apologética ${ }^{3}$. Pero lo más grave fue el abandono y la actitud despectiva de los laicos hacia los estudios eclesiásticos, lo que los relegó al ámbito eclesiástico y dio lugar a una cierta endogamia historiográfica, con la proliferación de revistas de historia vinculadas a las respectivas órdenes religiosas, y dejó al clero secular casi al margen del quehacer histórico.

El escaso desarrollo de las investigaciones históricas sobre el clero en el seno de la historia de la Iglesia tuvo que ver con su escasa o nula representación en las universidades, como tema docente y como línea de investigación. A diferencia de lo que sucedió en Francia, el estudio de las religiones no contó con otro marco institucional que no fuera el establecido por las instituciones eclesiásticas. Es decir, el desarrollo de la historia de la Iglesia en España estuvo casi siempre vinculado a la propia institución eclesiástica, ya fueran las órdenes religiosas, los seminarios, las facultades de teología (que desde 1868 no estaban vinculadas a las universidades públicas) o las universidades católicas, como las de Comillas, Pontifica de Salamanca y Gregoriana de Roma.

La historiografía generada por estos centros confesionales en la primera mitad del siglo xx, además de estar institucionalizada, se caracterizó por privilegiar las biografías de la jerarquía eclesiástica y las relaciones Iglesia-Estado, y utilizarla como arma de combate. Esta carencia contribuyó a alimentar el desconocimiento de la historiografía eclesiástica en las universidades públicas, lo que ralentizó el planteamiento de ciertos temas de investigación que, a diferencia de otros países, quedaron más circunscritos al ámbito de la historia confesional de la Iglesia. Además, en los primeros años del franquismo se instrumentalizó la historia eclesiástica a través de los Institutos de Historia de la Iglesia adscritos al Consejo Superior de Investigaciones Científicas ${ }^{4}$.

No obstante los aires renovadores del Concilio Vaticano II (1962-1965) y el cambio de actitud de diversos sectores de la Iglesia con la dictadura modificaron el discurso historiográfico y se fueron abandonando las viejas posiciones apologéticas, lo que hizo posible que, a partir de 1970, surgiera una nueva

3 Antonio Domínguez Ortiz, La sociedad española en el siglo XVII. II. El estamento eclesiástico, Madrid, CSIC, 1970, págs. 3-4 (ed. facsímil, Granada 1992). Algunas de las carencias aducidas fueron subsanadas unos años después, con la publicación del Diccionario de Historia Eclesiástica de España, Madrid, CSIC, 1972-1975, 4 vols., más otro de Suplemento, publicado en 1987; y Ricardo García-Villoslada (dir.), Historia de la Iglesia en España, Madrid, BAC, 1979, 5 vols.

4 Joaquim Maria Puigvert i Solá, «Los párrocos y las redes de sociabilidad parroquial en el mundo rural de Cataluña Moderna. Historiografía e Historia», Obradoiro de Historia Moderna, 22 (2013), págs. 168172 , analiza este proceso y ofrece abundante bibliografía. 
generación de historiadores eclesiásticos que produjeron trabajos históricos de gran calidad. Este proceso de renovación coincidió, en buena medida, con dos hechos de gran importancia: las reuniones científicas de Lyon y Cambridge, y las nuevas corrientes historiográficas. En primer lugar, las reuniones científicas sobre historia eclesiástica que se celebraron en Lyon, en 1963, y Cambridge, en 1968, impulsaron la renovación de la historia eclesiástica; pues, aunque todavía encontramos algunos temas tradicionales, como la decadencia moral y cultural del clero, predomina ya una temática nueva, orientada al estudio del rol histórico del bajo clero, como punto de enlace entre las elites y las masas, del cual dependía en gran parte la tónica dominante en la religiosidad de los fieles; y también se interesan por el estudio de su fisonomía social, cultural y económica, así como por su movilidad social ${ }^{5}$. Y en segundo lugar, las nuevas corrientes historiográficas socioeconómicas de los Annales impulsaron el estudio de los nuevos temas que se estaban desarrollando en Francia en torno al clero diocesano, a fin de conocer su fisonomía social, cultural y económica, así como su movilidad 6 .

Sin embargo el proceso fue lento. Es verdad que, de forma paulatina, la historia de la Iglesia dejó de ser un predio casi exclusivo de clérigos y religiosos, y su estudio se comenzó a generalizar en los ámbitos universitarios y de investigación, y esto ha provocado en las últimas décadas la eclosión de multitud de trabajos sobre aspectos relacionados con la Iglesia. Pero todavía en 1990 Roberto Fernández afirmaba, con un poco de exageración, que los historiadores de Cataluña (y de España) no tenían interés por la historia de la Iglesia, y casi ningún profesor aconsejaba a sus alumnos hacer una investigación sobre temas eclesiásticos, tanto por la poca atracción del tema como por la escasez bibliográfica que, además de erudita y poco interpretativa, «era escasa, parcial y esencialmente confeccionada por clérigos, celosos guardadores de los secretos de la Iglesia» ${ }^{7}$. Aunque esta afirmación puede ser válida a nivel general, hay que

5 VV. AA., Colloque d' histoire religieuse (Lyon, octubre 1963), Grenoble, Allier, 1963; y Derek BAKER (ed.), Miscellanea historiae ecclesiasticae, III. Coloque de Cambridge (settembre 1968), Louvain, Publications universitaires de Louvain, 1970.

6 Charles Berthelot du Chesnay, «Le clergé diocésain français au xviIIe siècle et les registres des insinuations ecclesiastiques», Revue d'Histoire Moderne et Contemporaine, 10 (1963), págs. 241-269; Dominique Julia, «Le clergé paroissaial dans le diocése de Reims à la fin du xvine siécle», Revue d'Histoire Moderne et Contemporaine, 13 (1966), págs. 195-216; Jean Meuvret, «La situation matérielle des membres du clergé séculier dans la France du xvIIIe siècle. Possibilités et limites des recherches», Revue d'Histoire de l'Eglise de France, 54 (1968), págs. 47-68; Jean-Paul Desaive, «Clergé rural et documents fiscaux. Les revénus et charges des prêtes des compagne au nord-est de Paris d'après enquétes fiscales des XviIe et XvIIIe siécles», Revue d'Histoire Moderne et Contemporaine, 17 (1970), págs. 921-948; etc.

7 Roberto Fernández Díaz, «La clerecía catalana en el Setecientos», en VV. AA., Eglésia $i$ societat a la Catalunya del s. XVIII, Cervera, UNED, 1990, vol. I, pág. 37. 
recalcar que, desde hacía unos lustros, algunos beneméritos profesores sugerían como tema de tesis de licenciatura y de doctorado el estudio de las instituciones eclesiásticas, como fue mi caso y el de otros doctorandos de las décadas del 70 y 80 del siglo pasado ${ }^{8}$. Sería en este contexto en el que, quien suscribe estas líneas, empezó sus investigaciones sobre la iglesia de Segovia en el siglo XVIII bajo la dirección del profesor Luis Miguel Enciso. Pero fueron el dialogo, el contacto con la historiografía italiana y francesa, y la riqueza documental de los archivos diocesanos, nacionales y del Secreto Vaticano los que me convencieron del interés y la necesidad de estudiar las instituciones eclesiásticas españolas, a las que he dedicado buena parte de mi actividad investigadora.

En mi opinión, los ámbitos de estudio más privilegiados han sido el clero secular y regular, destacando en los últimos años las monjas por el impulso de la historia de las mujeres y de género, así como las cofradías por la revitalización que han experimentado estas instituciones. Teniendo esto presente, me voy a limitar a hacer un pequeño balance historiográfico del clero español en el siglo XVIII, pero ciñéndome fundamentalmente a los estudios de ámbito universitario y de investigación, que es lo que mejor conozco ${ }^{9}$.

\section{El clero secular}

Uno de los principales condicionantes a que ha estado sometida la historiografía del clero secular ha sido la orfandad institucional que padece. Pues, a diferencia de las órdenes religiosas, con conciencia de grupo y mentalidad de

8 Maximiliano Barrio Gozalo, Estudio socio-económico de la Iglesia de Segovia en el siglo XVIII, Segovia, Caja Segovia, 1982 (Tesis doctoral, Valladolid, 1980); M. ${ }^{a}$ Luisa Candau Chacón, Iglesia y sociedad en la Campiña sevillana: La Vicaría de Écija (1697-1723), Sevilla, Diputación Provincial, 1986 (Tesis de licenciatura, 1985); Luis Javier Coronas VIDA, El Cabildo de la catedral de Jaén, 1700-1737, Granada, 1985 (Tesis de licenciatura inédita, aunque publicó un resumen en el artículo: «Los miembros del cabildo catedral de Jaén (1700-1737)», Chronica Nova, 15 (1986-1987), págs. 101-126); Julián P. DíAz López, La diócesis de Almería. Bienes y rentas de la Iglesia a través del Catastro de Ensenada, Granada, 1978 (Tesis de licenciatura inédita); Enrique Llopis Agelán, Las economías monásticas al final del Antiguo Régimen en Extremadura, Madrid, 1979 (Tesis doctoral inédita); Arturo Morgado García, Iglesia y sociedad en el Cádiz del siglo XviII, Cádiz, Universidad de Cádiz, 1989 (Tesis doctoral, Cádiz, 1988); Pilar Pueyo Colomina, Iglesia y sociedad zaragozanas a mediados del siglo хVIII, Zaragoza, Institución Fernando el Católico, 1991 (Tesis doctoral, Zaragoza, 1981); Joaquim M. Puigvert, Una parroquia catalana del segle XVIII a través de seva consueta, Barcelona, 1986 (Tesis de licenciatura, 1984); Oscar VilLán de la Fuente, Sociología del clero de la diócesis compostelana en el siglo XVIII, Santiago de Compostela, 1977 (Tesis de licenciatura inédita); etc.

9 Antonio L. Cortés y Miguel L. López-Guadalupe (eds.), La Iglesia española en la Edad Moderna. Balance historiográfico y perspectivas, Madrid, Abada, 2007, ofrece información de interés en algunos capítulos. Por otra parte, para los primeros investigadores ha sido de gran ayuda la obra de Christian Hernnan, L'Eglise d'Espagne sou le patronage royal (1476-1834), Madrid, Casa de Velázquez, 1988. 
promover los intereses de su orden y su historia, el clero secular es un grupo complejo y heterogéneo en el que encontramos obispos, canónigos, párrocos, beneficiados, capellanes y clérigos mercenarios o altaristas, y solo los miembros de los cabildos catedralicios tienen una clara conciencia de grupo. No obstante, en las últimas décadas, como consecuencia de las nuevas corrientes historiográficas, se han hecho grandes avances y se han publicado muchos artículos en revistas científicas y bastantes monografías, tanto sobre los obispos y los cabildos catedrales, como sobre el clero parroquial.

En su estudio han prevalecido dos líneas de investigación: una orientada al estudio de sus condiciones materiales, y otra hacia la delineación de lo que podríamos llamar una sociología del clero, a fin de recomponer su fisonomía en un determinado momento histórico.

La verificación de las condiciones económicas del clero, sobre todo del parroquial con cura de almas, es de gran importancia; pues la falta de ingresos suficientes para llevar una vida de acuerdo con la condición de su estado, podía favorecer el relajamiento de las costumbres y la indisciplina de un clero que, en muchos casos, no solo tenía deficiencias en el plano cultural sino que había abrazo la carrera eclesiástica sin una auténtica vocación ${ }^{10}$. En los momentos de crisis económica o en los años de malas cosechas es frecuente encontrar documentos que indican que «muchos clérigos, párrocos, beneficiados y capellanes, permanecen excomulgados por largo tiempo, al no poder pagar la cantidad que les corresponde del subsidio y excusado; otros abandonan el servicio y el disfrute de sus beneficios, porque no tienen congrua suficiente para sustentarse con los frutos eclesiásticos, ocupándose en ministerios profanos e indecentes al estado clerical, llevando la administración de personas seglares, dedicándose al comercio de compra-venta o poniendo tabernas en sus pueblos» ${ }^{11}$.

Los numerosos estudios que se han llevado a cabo sobre la situación económica del clero, tanto de los obispos y cabildos catedrales, como del clero parroquial, muestran que la situación material va mejorando desde Trento hasta la

10 Esta afirmación, que se repite en textos de la época y en los siglos siguientes, como hace François Lopez (Historia de España de Menéndez Pidal, XXI, Madrid, Espasa, 1987, pág. 797), al afirmar que «había muchos eclesiásticos, no porque abundaran las verdaderas vocaciones, sino porque este se ha hecho un modo de vivir para los que no tienen que comer y no quieren trabajar», hay que matizarla. Puede ser válida para entrar en alguna orden religiosa, pero no tanto para acceder a las órdenes sagradas en el clero secular, porque tenían que estar en posesión de un beneficio eclesiástico o una capellanía, o constituir un patronato que les permitiera vivir dignamente.

11 Archivo Secreto Vaticano, Arch. Nunz. Madrid, vols. 14 y 90. Memoriales del clero de los reinos de Castilla y León a Su Santidad, solicitando que no autorizase les impusieran sendas contribuciones sobre las rentas eclesiásticas. Años 1638 y 1687. Más información en BARRio GozAlo, Estudio socio-económico de la Iglesia, págs. 368-369. 
Guerra de la Independencia, con algunos momentos de recesión en el siglo XVII y primeros años del XVIII. Y esto ha permitido corregir las afirmaciones que todavía seguían repitiendo algunas historias generales en la década de los ochenta del siglo pasado, al afirmar que «en contraste con la holgada posición económica de los canónigos, la mayoría de los párrocos sufrían unas condiciones de pura subsistencia» ${ }^{12}$. Es verdad que las rentas de los obispos son muy elevadas, al igual que las de buena parte de los canónigos, pero las de los párrocos no eran tan bajas, como se ha venido diciendo ${ }^{13}$.

La segunda línea de investigación pretende trazar la sociología del clero en la época moderna, analizando una serie de elementos que van desde las condiciones económicas de los eclesiásticos a su extracción geográfica y social, de su preparación cultural al ejercicio de su función ministerial, y del reclutamiento del clero a las condiciones de la carrera eclesiástica.

El examen y tratamiento estadístico de las abundantes series documentales constituidas por los expedientes de órdenes, concursos a curatos y títulos patrimoniales, etc., pueden aportar una gran riqueza de resultados. A través de ellos se puede deducir, además de los datos relativos a las condiciones socio-profesionales de la familia del ordenando, el origen geográfico, los títulos académicos y los cargos desempeñados, así como también el tipo de renta que constituye el título para acceder a las órdenes sagradas y su importe. Un estudio de este tipo, si se hace a nivel diocesano y sobre un tiempo de media o larga duración, permite individualizar fenómenos de movilidad social, el carácter urbano o rural del reclutamiento eclesiástico y los cambios de orden social que se pueden experimentar.

También podemos hacernos una idea del nivel cultural del clero diocesano y su función religiosa por las noticias que aportan los expedientes de órdenes y los concursos a curatos o similares, así como las visitas pastorales. No obstante, el problema de la formación cultural del clero exige una mayor profundización, que en líneas generales aparece ligada al estudio de las instituciones docentes y, más en concreto, a la enseñanza impartida en los seminarios. Los numerosos estudios que se han llevado a cabo sobre los seminarios no me parece que sean lo suficiente iluminadores sobre la formación del clero, cuyo nivel general, según se puede deducir de los estudios existentes, experimenta cierta mejoría en la segunda mitad del setecientos con la puesta en funcionamiento de un buen

12 Historia General de España y América, X/2, Madrid, Rialp, 1984, págs. 536-537.

13 Maximiliano Barrio Gozalo, El Real Patronato y los Obispos españoles en el Antiguo Régimen (1565-1834), Madrid, Centros de Estudios Políticos y Constitucionales, 2004; Maximiliano Barrio Gozalo, El Clero en la España Moderna, Córdoba, CSIC / Caja Sur, 2010; etc. 
número de seminarios ${ }^{14}$. Se debería hacer más hincapié en el Ordo docendi que regía en cada seminario y los libros de texto que utilizaban, y así podríamos aproximarnos a las corrientes culturales e ideológicas que predominaban en la formación del clero en un momento determinado. Por ejemplo, si conociéramos esto para el último tercio del siglo XVIII, nos permitiría profundizar en la difusión del jansenismo entre el clero y las diferentes actitudes que mantuvo en los últimos años del siglo y primer tercio del siglo XIX, en concreto en la guerra de la Independencia y el Trienio liberal; es decir, su sintonía o rechazo con los afrancesados y el liberalismo ${ }^{15}$.

Pero ¿qué es lo que se ha hecho? Mucho. Por ejemplo, en los artículos publicados en las revistas científicas sobre historia de la Iglesia, entre 1940-1974, la presencia de títulos sobre el clero secular es muy escasa, y se refieren fundamentalmente a episcopologios y estudios sobre los cabildos, con ausencia casi total del clero parroquial ${ }^{16}$. Todavía a comienzos del presente siglo, María Luisa Candau nos dice que las bibliotecas universitarias españolas contenían 1.377 libros referidos a la Iglesia española y sus miembros en los tiempos modernos, publicados a partir de 1973. Pero solo 82 estaban relacionados con el clero secular: 33 sobre la jerarquía eclesiástica, de los cuales 14 son de contenido hagiográfico o episcopologios, y los 49 restantes abordan temas demográficos, económicos, sociológicos, culturales o comportamientos ${ }^{17}$. A estos títulos habría que sumar las muchas monografías que no están en las bibliotecas universitarias y, sobre todo, los numerosos artículos que se han publicado en las revistas científicas durante las cuatro últimas décadas, de forma que hoy se pueden contar por cientos los trabajos que han visto la luz sobre el clero secular y, también, sobre el parroquial.

La jerarquía eclesiástica es bien conocida, gracias los trabajos que ha publicado el que suscribe sobre la forma de provisión de los obispos y los aspectos

14 En el siglo XVIII se fundan 17 seminarios: Astorga (1766), Barbastro (1759), Calahorra (1776), Canarias (1777), Ciudad Rodrigo (1769), Ibiza (1794), Jaca (1747), Lérida (1722), Mallorca (1700), Orihuela (1742), Pamplona (1777), Salamanca (1779), Segorbe (1771) Segovia (1781), Teruel (1777), Zamora (1797) y Zaragoza (1788).

15 Cayetano Mas Galvañ, «Jansenismo y regalismo en el Seminario de San Fulgencio de Murcia», Anales de la Universidad de Alicante. Historia Moderna, 2 (1982), págs. 259-299; Angera NoLdA, «La ideología del clergat tarraconi a la crisi del Antic Regim», Anuari de la Societat d'Estudis d'Historia Ecclesiastica Moderna i Contemporania de Catalunya, 28 (1992), págs. 91-149; etc.

16 Jesús Longares Alonso y José M. Cuenca Toribio, Bibliografía de historia de la Iglesia, 1940-1974. Artículos de revistas, Valencia / Córdoba, Universidad de Valencia / Universidad de Córdoba, 1976.

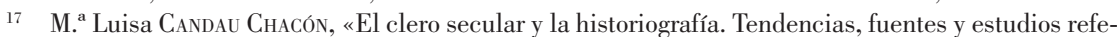
ridos a la modernidad», Revista de Historiografía, 2-II (2005), págs. 75-89. En este trabajo se recogen buena parte de los estudios publicados sobre el clero secular hasta 2003, por lo que remito a su consulta para no alargar la relación, limitándome a mencionar algunos de los más representativos o posteriores. 
socio-económicos de este grupo privilegiado en las distintas regiones españolas, y a las síntesis que he ofrecido en algunos libros sobre el patronato real y los obispos ${ }^{18}$. Estudios que han completado Artola Renedo, Joan Bada y otros autores, analizando las relaciones entre los obispos y el Estado en distintos momentos del siglo y apuntando interesantes ideas sobre la dificultad de compaginar la fidelidad al papa y al rey, así como la actitud de los obispos ante el regalismo y la ilustración ${ }^{19}$. Faltan, no obstante, biografías de prelados que permitan acercarnos al modo en que ejercieron su poder y sus relaciones con la sociedad diocesana, aunque hay algunas muy buenas ${ }^{20}$, sin olvidar la informa-

18 Maximiliano Barrio Gozalo, «Perfil socio-económico de una elite de poder: Los obispos de Castilla la Vieja, 1600-1840», Anthologica Annua, 28-29 (1981-1982), págs. 71-138; Maximiliano Barrio GoZALO, «Perfil socio-económico..., II: Los obispos del reino de León, 1660-1840», Anthologica Annua, 30-32 (1983-1984), págs. 209-291; Maximiliano Barrio Gozalo, «Perfil socio-económico..., III: Los obispos del reino de Galicia, 1600-1840»; Anthologica Annua, 32( 1985), págs. 11-107; Maximiliano Barrio Gozalo, «Perfil socio-económico..., IV: Los obispos de Castilla la Nueva y Extremadura, 1600-1840», Anthologica Annua, 33 (1986), págs. 159-302; Maximiliano Barrio Gozalo, «Perfil socio-económico..., V: Los obispos de Andalucía, 1600-1840», Anthologica Annua, 34 (1987), págs. 11-188; Maximiliano Barrio Gozalo, «Perfil socio-económico..., VI: Los obispos de Pamplona, 1556-1834», Anthologica Annua, 38 (1991), págs. 43-106; Maximiliano Barrio Gozalo, «Perfil socio-económico..., VII: Los obispos de Cartagena-Murcia, 1556-1834», Anthologica Annua, 39(1992), págs. 103-166; «Perfil socio-económico de una elite de poder de la Corona de Aragón, I: Los obispos del reino de Aragón (556-1834)», Anthologica Annua, 43 (1996), págs. 107-211; Maximiliano Barrio Gozalo, «Perfil socio-económico de los obispos del reino de Valencia, 1556-1834», Anthologica Annua, 50 (2003), págs. 312-371; Maximiliano Barrio Gozalo, «Los obispos de Cataluña durante el Antiguo Régimen, 1556-1834», Anthologica Annua, 53-54 (2006-2007), págs. 377-527; Maximiliano BARRiO Gozalo, «Estudio socio-económico de los obispos de Canarias durante el Antiguo Régimen, 1556-1834», Anuario de Estudios Atlánticos, 48 (2002), págs. 413-481; Maximiliano Barrio Gozalo, «La economía de los obispos en la España del Antiguo Régimen», en Luigi De Rosa, Ilaria Zilli y Ennio Di Nolfo (eds.), Fra Spazio e Tempo. Studi in onore di Luigi De Rosa, Napoli, Edizione scientifiche italiane, 1995, vol. I, págs. 33-57; Maximiliano Barrio Gozalo, «Sociología del alto clero en la España del Siglo Ilustrado», Manuscrits, 20 (2002), págs. 29-59; etc.; Maximiliano Barrio Gozalo, Los obispos de Castilla y León durante el Antiguo Régimen, Valladolid, Junta de Castilla y León, 2000; y Maximiliano Barrio Gozalo, El Real Patronato y los Obispos españoles del Antiguo Régimen (1556-1834), Madrid, Centro de Estudio Políticos y Constitucionales, 2004; J. F. Alcaraz, «El padre Rávago y las provisiones episcopales en el reinado de Fernando VI», Estudis, 18 (1992), págs. 173-198; Andoni Artola RenEdo, «La formación de los obispos procedentes del clero secular (1760-1788)», en José María Imízcoz Beunza y Álvaro Chaparro Sáinz (coords.), Educación, redes y producción de elites en el siglo XVIII, Madrid, Silex, 2013, págs. 387-415; etc.

19 Teófanes Egido López, «Actitudes regalistas de los obispos de Carlos III», en Carmen María Cremades Griñán (ed.), Estado y fiscalidad en el Antiguo Régimen, Murcia, Universidad de Murcia, 1989, págs. 67-83; Ramon CorTs, L'arquebisbe Félix Amat (1750-1824) i l'última Il.lustració espanyola, Barcelona, Facultad de Teología, 1992; Joaquim M. Puigvert (ed.), Bisbes, Il.lustració i Jansenisme a la Catalunya del segle XVIII, Vic, Eumo, 2001; Carlos Rodríguez LóPez-BreA, «Conflictos de jurisdicción eclesiástica en la España de finales del Antiguo Régimen: Los límites del episcopalismo borbónico», Hispania Sacra, 54 (2002), págs. 69-84; Joan BADA, «Las relacions entre els bisbes i l'Estat a la Catalunya de la Il.lustració», Manuscrits, 20 (2007), págs. 71-89; Andoni Artola Renedo, De Madrid a Roma. La fidelidad del episcopado en España (1760-1833), Gijón, Ediciones Trea, 2013; Maximiliano Barrio Gozalo, Los obispos españoles y el poder real en el siglo XVIII, (en prensa); etc.

20 Francisco Tort Mitjans, Biografía histórica de Francisco Armanya Font, OSA. Obispo de Lugo, Arzobispo de Tarragona, Imprenta Socitra, Vilanova i la Geltrú, 1967; y Francisco Tort Mitjans, El obispo de 
ción que el estudio de las visitas ad limina aporta sobre la actividad pastoral de los prelados ${ }^{21}$, así como los espolios, testamentos y librerías para acercarnos a su forma de vivir y morir ${ }^{22}$. No obstante, es llamativo el desconocimiento que tenemos de las curias episcopales, tanto de sus miembros como de sus ámbitos de actuación ${ }^{23}$. Por ejemplo, a pesar de la rica y abundante documentación que se conserva en los Archivos Diocesanos, se ha prestado poca atención al estudio de los tribunales de la curia, a pesar de que su estudio puede dar frutos insospechados para el mejor conocimiento del clero $^{24}$.

También son muchos los trabajos que han aparecido sobre los cabildos catedralicios. Rara es la diócesis que no cuenta con un estudio más o menos completo sobre el cabildo catedral, aunque la calidad de algunos es más que discutible. En las monografías que se escriben a finales del XIX y primera mitad del xx predominan los aspectos institucionales; a partir de la década del setenta ocupan la primacía los económicos, en consonancia con el auge que en ese momento tiene la historia económica; y desde finales del siglo pasado se da gran importancia al componente social, sus relaciones con las elites locales y su inserción en las redes del patronazgo, lo que motiva que muchas prebendas se convirtieran casi en algo patrimonial, al recaer durante varias generaciones en miembros de una misma familia por el sistema de las resignas in favorem

Barcelona Josep Climent (1706-1781). Contribución a la historia de la teología pastoral tarraconense en el siglo xvIII, Barcelona, Balmes, 1978; Juan José Tuñón Escalada, D. Agustín González Pisador, obispo de Oviedo (1760-1791). Iglesia y sociedad en Asturias, Oviedo, Real Instituto de Estudios Asturianos, 2000; Carlos M. Rodríguez López-Brea, Don Luis de Borbón. El Cardenal de los liberales (1777-1823), Toledo, Junta de Comunidades de Castilla-La Mancha, 2002; etc.

21 Vicente León Navarro, «Las visitas ad limina. Un estudio bibliográfico», Anales Valentinos, 49 (1999), págs. 195-214, analiza las publicaciones sobre las visitas, que, si ya eran muchas, han continuado aumentando en los años siguientes. Un buen estudio de las visitas de una diócesis en Ángel FernándEZ Collado, Los informes de visita ad limina de los arzobispos de Toledo, Cuenca, Universidad de Castilla-La Mancha, 2002; etc.

22 Mercedes Calvo Cruz, La contabilidad de espolios y vacantes: Diócesis de Canarias, 1753-1851, Las Palmas de Gran Canaria, Universidad de las Palmas de Gran Canaria, 2000.

23 J. M. Marqués, «Carreres de col.laboradors des Bibes de Girona, 1600-1774», Annals de l'Institut d'Estudis Girnonins, 16 (2000), págs. 125-178.

24 Antonio Cabeza Rodríguez, «Estudio del clero diocesano en el Antiguo Régimen a través de los fondos documentales de la Audiencias episcopales», Investigaciones Históricas, 11 (1991), págs. 35-52, escribe unas páginas de gran interés; M. a Luisa Candau Chacón, Los delitos y las penas en el mundo eclesiástico sevillano del siglo XVIII, Sevilla, Diputación Provincial de Sevilla, 1991, hace un estudio mucho más completo; y Antonio Prada Santamaría, «El Tribunal diocesano de Pamplona contra el Tribunal del rey: la inmunidad eclesiástica local en cuestión», Príncipe de Viana, 237 (2006), págs. 185-210, analiza un tema que provocaba muchas fricciones entre la potestad civil y la eclesiástica; etc. Sin embargo, el estudio más completo de un Tribunal diocesano es el de Julián Recuenco Pérez, La actuación del Tribunal Diocesano de Cuenca en la Crisis del antiguo Régimen, 1808-1833, Cuenca, Universidad de Castilla-La Mancha, 2011, aunque rebasa ligeramente nuestro espacio temporal. 
y las coadjutorías con derecho a sucesión ${ }^{25}$. Es decir, el interés por el estudio de los cabildos catedralicios en los últimos lustros ha estado en relación con la abundancia y fácil localización de la documentación, y también por la sintonía con las tendencias historiográficas sobre las elites de poder y de la reproducción social ${ }^{26}$.

En los años sesenta y setenta del siglo pasado comenzaron a aparecer monografías sobre algunos cabildos catedralicios castellanos, como los de Ávila y León, que abarcan desde la época moderna a la contemporánea, y éste último trazó la línea institucional y existencial que seguirían otros estudios posterio$\operatorname{res}^{27}$. Esta tendencia se continuó en los años siguientes, aunque se fueron introduciendo de forma paulatina aspectos socioeconómicos, como se puede observar en la obra de Rafael Vázquez sobre el cabildo de Córdoba, Coronas Vida sobre los capitulares de Jaén, Antonio Cánovas sobre cabildo de Murcia y otros más ${ }^{28}$. En la Corona de Aragón los trabajos son más limitados y, en general, se ocupan del estudio de la estructura organizativa y las relaciones con otras instituciones de poder. La obra más importante es la de Montserrat Jiménez Sureda sobre el cabildo de Gerona, que estudia los aspectos institucionales y políticos, los familiares y culturales ${ }^{29}$. Otros cabildos no cuentan con obras específicas,

25 Entre los estudios historiográficos sobre sobre los cabildos se puede contar con Roberto J. LÓPEZ LÓPEZ, «Investigaciones recientes sobre los cabildos catedralicios gallegos durante la Edad Moderna», en Germán Ramallo Asensio (ed.), La catedrales españolas: del Barroco a los historicismos, Murcia, Universidad de Murcia, 2003, págs. 759-777; Rafael MARín LóPEZ, «Historiografía sobre los cabildos eclesiásticos. Estado de la cuestión y perspectivas de investigación», en Antonio Cortés Peña y Miguel L. López-Guadalupe (eds.), La Iglesia española, págs. 105-112, que se centra en los publicado entre 1995 y 2005, sobre todo de Andalucía; Antonio J. Rodríguez, «Cabildos catedralicios y clero capitular en el Antiguo Régimen: estado de la cuestión», Revista de Historiografía, 13 (2010), págs. 82-99. Por último, la revista Memoria Ecclesiae, 29 (2006) ofrece mucha información sobre los cabildos y los capitulares.

26 Antonio J. Díaz Rodríguez, El clero catedralicio en la España Moderna. Los miembros del Cabildo catedral de Córdoba, 1475-1808, Murcia, Universidad de Murcia, 2012, ofrece un estudio modélico, aunque no hay que olvidar las aportaciones para los siglos xvi y xvi de A. Cabeza (Palencia, 1996), A. Irigoyen (Murcia, 2000), J. M. Latorre (Aragón, 2009), R. Marín (Granada, 1998), Quintana (Canarias, 2004), R. Sánchez (Toledo, 2000), etc.

27 Juan R. López Arévalo, Un cabildo catedral de la vieja Castilla, Ávila. Su estructura jurídica, Madrid, CSIC, 1966; T. ViLlacorTa, El cabildo catedral de León. Estudio histórico-jurídico, siglos XII-XIX, León, Diputación Provincial de León, 1974.

28 Rafael Vázquez Lesmes, Córdoba y su cabildo catedralicio en la Edad Moderna, Córdoba, Caja de Ahorros de Córdoba, 1987; Luis J. Coronas VIDA, «Los miembros del cabildo catedral de Jaén (1700-1737», Chronica Nova, 15 (1986-1987), págs. 101-126; Luis C. GARCía Figuerola, La economía del cabildo salmantino en el siglo XVIII, Salamanca, Universidad de Salamanca, 1989; Antonio Cánovas Botía, Auge y decadencia de una institución eclesial: el cabildo catedral de Murcia en el siglo XVIII. Iglesia y sociedad, Murcia, Universidad de Murcia, 1994; etc.

29 Montserrat Jiménez Sureda, L'Esglesia catalana sota la monarquía dels Borbons. La Catedral de Girona en el segle XVIII, Girona, Abadía de Montserrat, 1999; Francisco Castillón CoRTAda, «Estructura del Cabildo catedralicio de Lleida durante el siglo XVIII, en VV. AA., Esglèsia $i$ societat a la Catalunya del s. XVIII, vol. II, págs. 99-117; Antoni Jordà Fernández, «Els canonges de la Seu de Tarragona durant el segle xviII: 
pero los estudios que se han hecho sobre la diócesis dedican muchas páginas a la institución capitular, como sucede en Cádiz, Segovia, Valladolid y, en general, en la reciente Historia de las diócesis españolas, publicada por la $\mathrm{BAC}^{30}$.

El patrimonio de las mesas capitulares y su administración ha sido objeto de gran interés y llegó a convertirse en el objetivo principal de algunos estudios. Basta con recordar las páginas sobre la economía de los cabildos de Córdoba, Lugo, Murcia, Salamanca, Segovia y otros más ${ }^{31}$.

A pesar de las lagunas existentes, cada vez conocemos mejor el papel que el nepotismo, los lazos de parentesco y patronazgo juraron en el reclutamiento de los capitulares ${ }^{32}$, así como las relaciones con el poder. Pues en un grupo social, como el cabildo, pleitista y puntilloso, reacio a la reforma y renuente al menoscabo de sus prerrogativas, las relaciones con el poder generan lazos y conflictos, ya sea por causas económicas, de jurisdicción o de protocolo ${ }^{33}$. En

aproximació al seu estudi», en Esglèsia $i$ societat, vol. II, págs. 255-265; José M. LATORRE Ciria, «Perfiles de un grupo eclesiástico. Los canónigos aragoneses del último tercio del siglo XVIII", Hispania Sacra, 124 (2009), págs. 545-569; etc. Hay estudios de gran interés sobre cabildos catalanes y aragoneses referentes a los siglos XVI y XVII.

30 Arturo Morgado, Iglesia y sociedad en el Cádiz del siglo XVIII, Cádiz, Universidad de Cádiz, 1989, págs. 87-117; Pablo Antón Sole, La Iglesia gaditana en el siglo XVIII, Cádiz, Universidad de Cádiz, 1994, págs. 281-304; Maximiliano Barrio Gozalo, Iglesia y sociedad en Segovia. Siglo XVI-XIX, Valladolid, Universidad de Valladolid, 2005, págs. 93-108; y Maximiliano Barrio Gozalo, Religión y sociedad en Valladolid y su Obispado, Valladolid, Ayuntamiento / Instituto de Historia Simancas, 2016, págs. 111-130; etc.

31 Antonio López Estadillo, «La mesa capitular de la catedral de Córdoba y la gestión económica de su patrimonio rústico (1700-1840)", en Ricardo Robledo (ed.), Actas del VIII congreso de la Asociación española de Historia Económica, Zaragoza, 2005, versión digital, págs. 1-20; M. ${ }^{a}$ Concepción Burgo LóPEZ, «La estructura económica del Cabildo de Lugo a finales del siglo XVIII», Obradoiro, 2 (1993), págs. 65-84; M. ${ }^{a}$ del Carmen Melendreras, «Estudio de la renta de distribución del cabildo de la catedral de Murcia a finales del Antiguo Régimen (1763-1790)», Contrastes. Revista de Historia Moderna, 2 (1986), págs. 167-200; García Figuerola, La economía del cabildo salmantino, 1989; Barrio Gozalo, Estudio socioeconómico, págs. 302-364; etc.

32 Antonio J. Díaz Rodríguez, «El precio del nepotismo. Coadjutoría y resigna en las catedrales andaluzas (s. Xvi-XviII)», Chronica Nova, 35 (2009), págs. 387-309; Montserrat JiménEz SuredA, «Alienigenas, regnícolas y naturales. Monarquía y elites en una catedral catalana del siglo XVIII», en Juan L. CASTELLANOS et al. (eds.), La pluma, la mitra y la espada. Estudios de Historia Institucional en la Edad Moderna, Madrid, Marcial Pons, 2000, págs. 271-290; Francisco J. SANZ DE LA Higuera, «Clérigos a la sombra de un pariente en el siglo XVIII burgalés», Hispania Sacra, 120 (2007), págs. 563-594; Arturo Iglesias OrTega, «Nepotismo y patronazgo en la Galicia moderna: el cabildo catedralicio de Santiago de Compostela», Hispania Sacra, 68 (2016), págs. 259-280; etc.

33 Xavier Antón Pelayo y Montserrat Jiménez Sureda; «Reforma y conflictes dins la Catedarl de Girona en la segona meitat del segle XVIII», Analecta Sacra Tarraconensia, 67/1 (1994), págs. 197-206; Ana M. a SÁnchez Rodríguez, «Las ceremonias públicas en Lugo durante la Edad Moderna. Conflictos de preeminencias entre el obispo, cabildo y concejo», Obradoiro, 13 (2004), págs. 295-211; Antonio L. Cortés PEÑA, «Conflictos jurisdiccionales entre la Iglesia y los poderes civiles en el siglo XvIII, en VV. AA., Iglesias y Fronteras. V Jornadas de Historia en la Abadía de Alcalá la Real, Jaén, Ayuntamiento de Jaén, 2005, págs. 127-140; Pedro C. Quintana, «El Cabildo catedral de Canarias: una elite socioeconómica e ideológica de ámbito regional», Revista de Historia Moderna, 26 (2008), págs. 221-248; etc. 
cambio, todavía no conocemos para este siglo lo suficiente de la familia de los capitulares y su personal de servicio, su estilo de vida, bibliotecas, mecenazgo, niveles culturales y religiosidad, y quizá sea el cabildo de la catedral de Valencia sobre el que tenemos más información para el setecientos en los volúmenes coordinados por Emilio Callado ${ }^{34}$.

Mucho menos estudiados han sido los cabildos de las más de cien colegiatas que había en España, quizá por la dispersión de sus archivos o por su menor relevancia socioeconómica. Aunque su clero no era tan rico como el de las catedrales, se observan grandes diferencias de unas regiones a otras. En Castilla son abundantes, pero en Galicia son pobres en general, en el País Vasco tienen un patrimonio respetable, en Andalucía hay algunos muy importantes, como los Alcalá la Real, Antequera, Baza, Jerez o Úbeda; en ambas Castillas destacan los de Alcalá de Henares, Talavera de la Reina, Toro, Villafranca del Bierzo, etc.; en Navarra el de Roncesvalles, y en la Corona de Aragón, que son muy numerosos, se pueden señalar los de Ager, Alicante, Játiva, Santa María de Calatayud, Santa Ana de Barcelona, Manresa etc. De todas formas, a pesar de las carencias, los prebendados de las colegiatas han comenzado a ser mejor atendidos, como reflejo de los grandes capítulos catedrales ${ }^{35}$. No obstante las diferencias que existen entre ellos son demasiado profundas para establecer comparaciones entre las distintas colegiatas, tanto por su dotación como por la forma de provisión de los capitulares ${ }^{36}$.

34 Carlos Martínez Rueda, «Crónica de una crisis. El Cabildo de Bilbao en el siglo XviII», Letras de Deusto, 18(1988), págs. 73-91; Ofelia Rey Castelao, «El alto clero gallego en tiempos de Carlos III», en VV. AA., Carlos III y su Siglo, Madrid, Universidad Complutense, 1990, vol. II, págs. 579-600; Arturo Morgado, «Vida de un canónigo. Percepción, origen y status de vida del alto clero durante el Antiguo Régimen», en Francisco J. Aranda Pérez (coord.), Sociedad y elites eclesiásticas en la España Moderna, Cuenca, Universidad de Castilla-La Mancha, 2000, págs. 77-100; Antonio Irigoyen, «Aproximación al estudio del servicio doméstico del alto clero de Murcia durante el siglo xvIII», Obradoiro, 19 (2010), págs. 307-327; Emilio CaLLado (ed.), La Catedral ilustrada. Iglesia, sociedad y cultura en la Valencia del siglo XVIII, Valencia, Institució Alfons el Magnànim, 2013-2015, 3 vols.

35 Un ejemplo tenemos en el trabajo de Joan Alonso Llorca et al., «Particularidades de los archivos de colegiatas: el Archivo de la colegiata de Santa María de Xativa», Memoria Ecclesiae, 4 (1993), págs. 261-281.

36 Francesc Fité Llevot, «La secularización de la canónica de San Pedro de Ager», Memoria Ecclesiae, 8 (1996), págs. 149-174; Alberto García Dengra, La Santa e Insigne Iglesia Colegial de Baza, Almería, Imprenta Úbeda, 1996; Maximiliano Barrio Gozalo, «La colegiata de Medina del Campo en los tiempos modernos. Aspectos institucionales y económicos», en VV. AA., Abadía. II Jornadas de Historia en la Abadía de Alcalá la Real, Jaén, Ayuntamiento de Jaén, 1999, págs. 62-66; M. Teresa Benito Aguado, La sociedad vitoriana en el siglo XVIII: el clero, espectador y protagonista. Bilbao, Universidad del País Vasco, 2001; M. a Teresa Díaz Mohedano, «La Iglesia colegial de Antequera. Organización y funcionamiento de su cabildo», Revista de estudios antequeranos, 12 (2001), págs. 413-426; Baudilio Barreiro y Ofelia Rey Castelao, «Catedrales de segundo orden, las colegiatas de Galicia en la Edad Moderna», Semata, As institucións galegas na Historia, 15 (2004), págs. 281-315; Carlos Ayllón GutiérRez, «Iglesia y poder en el Marquesado de Villena. Los orígenes de la colegiata de Belmonte», Hispania Sacra, 121 (2008), págs. 95-130; etc. 
Aunque algunos autores continúan diciendo que el bajo clero o clero parroquial sigue siendo el gran olvidado, yo me atrevo a decir que no es así. Cuando en 1988 escribí un artículo sobre el estado de la cuestión del bajo clero, decía que se había escrito muy poco sobre este colectivo ${ }^{37}$, y Domínguez Ortiz, pionero en la renovación de la historiografía eclesiástica, se limitaba a trazar unas pinceladas ricas y sugestivas, pero que pecaban de falta de precisión por la generalización que empleaba ${ }^{38}$. Sin embargo, hoy las cosas han cambiado, y son muchos los trabajos que se han publicado sobre algunos aspectos de este colectivo en todas las regiones españolas ${ }^{39}$, aunque faltan estudios que ofrezcan una visión global y algunas zonas geográficas están escasamente tratadas, lo que impide realizar una historia comparada del clero parroquial en todo el territorio español ${ }^{40}$. A pesar de estas limitaciones, los estudios existentes permiten conocer los rasgos esenciales de la procedencia del clero parroquial, su nivel cultural y su adecuación al modelo esbozado por el concilio de Trento, reforzado por las reformas ilustradas, aunque todavía hay que profundizar en estos puntos y en otros muchos como la parroquia y la organización beneficial, etc.

La forma de reclutamiento y la estructura beneficial determinan, en buena medida, que la mayor parte de clero parroquial proceda del mismo obispado.

${ }_{37}$ Maximiliano Barrio Gozalo, «El bajo clero en la España del siglo XVIII. Estado de la cuestión, problema y direcciones de la investigación actual», en VV. AA., Carlos III y su Siglo, vol. I, págs. 793-805.

38 Antonio Domínguez Ortiz, La Sociedad española en el siglo XVIII, Madrid, CSIC, 1955, págs. 142149; y Antonio Domínguez OrTiz, La Sociedad española en el siglo XVII. II, El estamento eclesiástico, Madrid, CSIC, 1970, págs. 49-67. Estas dos obras están refundidas parcialmente en Las clases privilegiadas en la España del Antiguo Régimen, Madrid, Istmo, 1973, y han sido reeditadas.

39 Entre los muchos estudios que se pueden citar, me limito a mencionar algunos libros: M. ${ }^{a}$ Luisa Candau Chacón, La carrera eclesiástica en el siglo XVIII. Modelo, cauces y formas de promoción en la Sevilla rural, Sevilla, Universidad de Sevilla, 1993; M. ${ }^{a}$ Luisa Candau Chacón, El Clero rural de Sevilla en el siglo XVIII, Sevilla, Caja Rural, 1994; Josué Fonseca, El Clero en Cantabria en la Edad Moderna, Santander, Universidad de Cantabria, 1996; etc., y varios artículos: Santiago Aragón Mateos, «Notas sobre el clero secular en el Antiguo Régimen. Los presbíteros en el obispado de Coria en el siglo XVIII», Hispania Sacra, 89 (1992), págs. 171-216; Maximiliano BARRio Gozalo, «El clero parroquial en la España moderna. Estilo de vida y aspectos socioeconómicos», Cuadernos de Investigaciones Históricas, 24 (2007), págs. 311-342; Maximiliano Barrio Gozalo, «Muchos clérigos y pocos curas: El acceso a la clerecía y los beneficios menores en la España Moderna», Cuadernos de Investigación Histórica, 25 (2008), págs. 293-332; Isidro DuBERT, «El clero rural en Galicia a fines del Antiguo Régimen», en Miguel Romaní Martínez y María Angeles Novoa Gómez (coords.), Homenaje a José García Oro, Santiago de Compostela, Universidad de Santiago, 2002, págs. 101-118; Ofelia Rey Castelao, «El clero de Santiago de Compostela y la historia en la Edad Moderna», Compostelanum, 50 (2005), págs. 627-654; José A. Vázquez Vilanova, «El clero de Santiago de Compostela a finales del siglo XVIII», Compostelanum, 50 (2005), págs. 579-607; Antonio Irigoyen, «Ciudad y clero secular. Imágenes del mundo urbano desde la perspectiva eclesiástica», Revista de historiografía, 16 (2012), págs. 82-90; Joaquim M. Puigvert, «Los párrocos y las redes de sociabilidad parroquial en el mundo rural de la Cataluña moderna: historiografía e historias», Obradoiro, 22 (2013), págs. 167-206; etc.

40 Entre los estudios de ámbito nacional se pueden mencionar los libros de Barrio Gozalo, El Clero en la España Moderna; y Arturo Morgado García, Ser clérigo en la España del Antiguo Régimen, Cádiz, Universidad de Cádiz, 2000; etc. 
En las diócesis en que la totalidad o gran parte de los beneficios son patrimoniales sus titulares son naturales del lugar donde está ubicado el beneficio; en cambio, si los curatos son de libre provisión y se proveen por concurso abierto a clérigos foráneos, la presencia de extradiocesanos es grande, como sucede en Cuenca, Segovia, Toledo, etc., donde casi la mitad de los párrocos proceden de otros obispados, mientras que la mayoría de los vicarios, tenientes, beneficiados y capellanes son originarios del obispado. Es decir, se da cierta movilidad geográfica en los párrocos o rectores, que se potencia después de la firma del concordato de 1753, poca en los beneficiados y casi ninguna en los capellanes y clérigos mercenarios.

Lo que sabemos sobre la procedencia social del bajo clero pone de manifiesto que la mayor parte se recluta en los sectores mesocráticos: campesinos acomodados, artesanos y profesiones liberales, etc. La presencia de los sectores más humildes es muy baja y, en su mayoría, son servidores de nobles y del alto clero o de familias humildes que obtienen beca para realizar estudios en alguno de los colegios o seminarios existentes. Hay que matizar, no obstante, que donde predominan los beneficios de patronato laical sus titulares son segundones de la familia del patrono e hijos de criados y deudos; en cambio, donde prevalecen los beneficios de libre provisión su procedencia social es más variada y predominan los de origen mesocrático.

Al hablar del nivel cultural del clero se suele afirmar que era muy deficiente y así lo reconoce el fiscal general del Consejo de Castilla, cuando en 1713 propone a los obispos la erección de colegios o seminarios para la formación de los aspirantes a la clerecía. Algunos prelados, como los de Badajoz, Cartagena y otros, lo reconocen y aplauden la idea del fiscal, pero otros, como los de Guadix y Valladolid, opinan que no hay que exagerar, porque se los exigía lo que mandaban los cánones ${ }^{41}$. De todas formas, a medida que avanza el siglo, mejora sensiblemente el nivel cultural del clero parroquial, al generalizarse las conferencias morales y los exámenes en la visita pastoral. Mejoras que se consolidan en la segunda mitad del siglo con la aplicación del concordato del 1753, la erección de seminarios y la reforma beneficial, de forma que al finalizar la centuria el número de clérigos ignorantes es muy bajo, y son muchos los párrocos que se han graduado en teología o derecho en alguna de las universidades del reino ${ }^{42}$.

41 Maximiliano Barrio Gozalo, «El clero bajo sospecha a principios del siglo XVIII. El informe de Macanaz y la respuesta de los obispos», Investigaciones Históricas, 22 (2002), págs. 47-62.

42 Manuel Martín Riego, Las conferencias morales y la formación permanente del clero en la archidiócesis de Sevilla (siglos XVIII al XX), Sevilla, Fundación Infanta María Luisa, 1997; Joaquim M. Puigvert, «L'episcopat i la formació del baix clergat al segle XVII. L'exemple de las confèrencies eclesiàstiques», en Joaquim M. Puigvert (ed.), Bisbes, Il.lustració, págs. 124-137. 
El desarrollo de los decretos tridentinos fue elaborando un modelo del párroco ideal, que la literatura religiosa desarrolló ${ }^{43}$ y los reformistas ilustrados enriquecieron en sus funciones, a fin de que su actividad pastoral no quedase limitada a lo religioso sino también a la utilidad social. Para ello debía tener una congrua suficiente, a fin de que no se distrajera en oficios incompatibles con su estado; guardar la residencia, tener buena formación, administrar bien las rentas de la fábrica de la iglesia, atender a los enfermos y necesitados, fomentar entre sus feligreses la educación de la agricultura y la industria, etc. Pero ¿̇este proyecto reformista se llevó a cabo? El estudio de las visitas pastorales y las fuentes judiciales han mostrado que el proyecto ideal del párroco no se consiguió en su totalidad, pero son muchos los indicios que permiten afirmar que a lo largo del siglo se producen avances importantes. Mejora sensiblemente su nivel cultural y la imagen de unos párrocos ignorantes y con pocos recursos económicos no resiste el análisis en las diócesis españolas donde los curatos eran de libre provisión y se accedía por concurso, máxime después de la firma del concordato de 1753 y la reforma beneficial que se realizó en muchas diócesis ${ }^{44}$. Además, en la segunda mitad del siglo, el clero parroquial se convierte en un activo colaborador de la política reformista. Campomanes los considera colaboradores natos de las Sociedades Económicas a las que pueden hacer llegar información sobre la realidad socioeconómica de sus parroquias y actuar como difusores de las iniciativas y proyectos de estas asociaciones. Y Godoy los utiliza como mediadores culturales para instruir a los campesinos en los conocimientos útiles a la economía rural y a la industria, y decide publicar el Semanario de Agricultura y Artes dirigido a los párrocos en 1797, para que informen a sus feligreses de los adelantos y mejoras que se producen ${ }^{45}$.

Hay que resaltar, no obstante, que la mayor parte de los estudios que se han hecho sobre el bajo clero se refieren a los párrocos o rectores, mientras que los

$43 \quad$ Isidro DuBERT, «La domesticación, la homogeneización y la asimilación de las conductas del clero gallego del Antiguo Régimen a la identidad del modelo tridentino, 1600-1850», en Javier M. Donezar y Manuel Pérez Ledesma (eds.), Antiguo Régimen y liberalismo, Madrid, Alanza, 1994, vol. II, págs. 477-495; José L. BETRÁN, «El pastor de almas: la imagen del buen cura a través de la literatura de instrucción sacerdotal en la contrarreforma española», en Eliseo Serrano, Antonio L. Cortés y José L. Betrán (coords.), Discurso religioso y contrarreforma, Zaragoza, Institución Fernando el Católico, 2005, págs. 161-201; etc.

44 Para evitar hacer una relación de los muchos trabajos que se han ocupado del tema en distintas regiones españolas remito a las síntesis de Maximiliano Barrio Gozalo, El sistema beneficial de la Iglesia durante el Antiguo Régimen (1475-1834), Alicante, Universidad de Alicante, 2010, págs. 120-140 y 165-206; Arturo Morgado, «El clero secular en la España moderna; un balance historiográfico», en Antonio Cortés Peña y Miguel L. López-Guadalupe (eds.), La iglesia española, págs. 39-73; Joaquim M. PuigverT, «Los párrocos y las redes...", págs.187-197; etc.

45 Elisabel Larriba y Gérard Dufour, El Semanario de Agricultura y Artes dirigido a los párrocos (1797-1808), Valladolid, Ámbito, 1997. 
referentes a los simples beneficiados y capellanes, que constituyen la mayoría de los miembros del bajo clero, no son tan numerosos, si exceptuamos los beneficios personados de Cataluña ${ }^{46}$. Pues, la mayoría de los trabajos que hay sobre las capellanías, apenas se ocupan de los capellanes que las sirven ${ }^{47}$. Es verdad que la diversidad de fuentes que hay que consultar dificulta su estudio. Por ejemplo, para valorar los ingresos del bajo clero hay que analizar los distintos conceptos que conforman la renta global, es decir, los ingresos provenientes de los bienes patrimoniales, cuya investigación resulta compleja, y los procedentes del beneficio que disfruta, como son los bienes dotales, los frutos decimales que le corresponden y los emolumentos que percibe por el desempeño de las tareas ministeriales ${ }^{48}$.

Algunos autores se han acercado al estudio del comportamiento del clero y sus desviaciones a través de las visitas pastorales, pero también de los testamentos y la documentación de los tribunales eclesiásticos, que antes mencioné y ofrecen un rico abanico de posibilidades para conocer su estilo de vida, relación con el pueblo y el papel de la familia del clérigo ${ }^{49}$.

A pesar de las distintas posibilidades de acercarse al estudio de la parroquia rural, tanto desde la perspectiva de la historia de la Iglesia como de la historia religiosa, no ha suscitado interés entre los historiadores profesionales hasta finales del siglo pasado, en que se asiste a un preocupación creciente por la parroquia rural, como espacio común en el que se mezclan las manifes-

46 Pedro Fatjó Gómez, «El beneficio personado. Un instrumento de promoción entre el clero secular (s. XVII)», Analecta Sacra Tarraconensia, 67/1 (1997), págs. 925-941; J. M. MARQQús, «Fundadores de beneficios en el obispado de Gerona (ss. XVI-XVIII)», Anthologica Annua, 36 (1989), págs. 493-507; y J. M. MarQués, «Els personas i permutes de beneficis del Bibat de Girona (s. XVII-XVIII)», Annals de l'Institut d'Estudis Gironnins, 40 (1999), págs. 145-183; etc.

47 Eugenia Fernández Cubeiro, «Una práctica de la sociedad rural: aproximación al estudio de las capellanías de la diócesis compostelana en los siglos XVII-XVIII», en A. Eiras Roel et al., La historia social de Galicia en sus fuentes y protocolos, Santiago de Compostela, Universidad de Santiago de Compostela, 1981; Juan Pro Ruiz, «Las Capellanías: familia, Iglesia y propiedad en el Antiguo Régimen», Hispania Sacra, 41 (1989), págs. 585-602; Manuel MarTín Riego, «Las capellanías en la archidiócesis de Sevilla. Siglo XvIII», Isidorianum, 1/1 (1992), págs. 171-204; Enrique SoRia MeSA, «Las capellanías en la Castilla moderna: familias y ascenso social», en Antonio Irigoyen y Antonio L. Pérez (eds.), Familia, trasmisión y perpetuación (Siglos XVI-XIX), Murcia, Universidad de Murcia, 2002, págs. 135-148; Silvia M. a PéreZ GonZÁLEZ, «Los beneficios parroquiales: un acercamiento al estudio del clero secular», Hispania Sacra, 64 (2012), págs. 497-52; etc.

48 Maximiliano BARrio Gozalo, «Las condiciones materiales del clero parroquial del obispado de Segovia en el siglo XVIII», Investigaciones Históricas, 11 (1991), págs. 9-34, y 12 (1992), págs. 113-138.

49 Candau Chacón, Los delitos y las penas, 1993; Isabel Testón Núñez y Mercedes Santillana PéREZ, «El clero cacereño durante los siglos XVI al XVIII: comportamiento y mentalidad», en VV. AA., Historia Moderna. Actas de las II Jornadas de Metodología y Didáctica de la Historia, Cáceres, 1983, págs. 463472; Baudilio BARREIRo, «El clero de la diócesis de Santiago: estructura y comportamientos (siglos XVI-XIX)», Compostellanum, 33 (1988), págs. 469-507; Avelina Benítez BAREA, Clero y mundo rural en el siglo XVIII. La Comarca gaditana de la Janda, Cádiz, Universidad de Cádiz, 2013; etc. 
taciones sociales y espirituales, como ha puesto de manifiesto Joaquín María Puigvert, siendo Cataluña y Galicia los espacios mejor estudiados. Después del concordato de 1753 la política religiosa de los monarcas estuvo orientada a reforzar la estructura parroquial y fortalecer la posición de los párrocos frente a los simples beneficiados y capellanes. Pero, como en Galicia, al igual que sucede en otras regiones, casi las tres cuartas partes de las parroquias eran de patronato de la nobleza, monasterios, cabildos o comunidades de vecinos, los resultados fueron muy escasos ${ }^{50}$.

Tampoco ha suscitado demasiado interés el estudio de las instituciones del bajo clero conocidas con el nombre de universidades, cabildos o juntas de clérigos, curas o beneficiados. La mayoría son de origen medieval, pero una característica del siglo XVIII es la formación de corporaciones de curas de diferentes diócesis para reivindicar sus presuntos derechos, tanto de carácter económico como social y eclesial, aunque no convergen hacia un progresismo revolucionario como sucede en Francia con los representantes del bajo clero en los Estados Generales. Algunas de estas asociaciones tienen su origen en épocas anteriores, como sucede en Pamplona, otras surgen a principios del XVIII, como en Mallorca y Salamanca, y no pocas lo hacen en la segunda mitad de la centuria, como ocurre en Oviedo y Segovia ${ }^{51}$.

Po último, al estudiar los aspectos de la vida del clero secular hay que tener en cuenta las grandes diferencias que se observan entre los miembros del personal eclesiástico, fruto del sistema beneficial que las sustenta. De aquí la necesidad de profundizar en el estudio de la estructura beneficial de la Iglesia española, pues el beneficio eclesiástico es el gozne en torno al cual gira la estructura del clero diocesano, ya que en función de él se jerarquiza y diferencia, tanto por su función como por sus condiciones económicas. La obtención de un beneficio era importante, no solo por el disfrute inmediato de una renta, sino porque abría las puertas a la carrera eclesiástica y permitía ascender a un be-

50 Joaquim M. Puigvert, Una parroquia catalana del segle XVIII a través de la seva consueta, Barcelona, Fundació Vives Casajuana, 1986; y Joaquim M. Puigvert, Esglesía, territorio i sociabilitat (s. XVII-XIX), Vic, Eumo, 2001. De gran interés resulta el monográfico de la revista Obradoiro, 22 (2013), con las aportaciones de SaAvedra et al. sobre Galicia (págs. 93-128), Rubio sobre León (págs. 134-157), Puigvert sobre Cataluña (págs. 168-186), y Morgado sobre Cádiz (págs. 207-230). Por otra parte, la revista Memoria Ecclesiae, 8 y 9 (1996), analiza la historia de la parroquia y sus archivos.

51 José M. Latorre Ciria, «El clero del obispado de Teruel en 1753», Aragonia Sacra, 6 (1991), págs. 113-149; Francisco J. ARANDA, «El clero parroquial también se acabilda. El cabildo de párrocos y beneficiados de Toledo», en Francisco J. Aranda (coord.), Sociedad, y elites eclesiásticas en la España Moderna, Cuenca, Universidad de Castilla-La Mancha, 2000, págs. 257-287; Mariano Sanz González, "La unión o confederación de curas párrocos de la diócesis de Segovia», Anthologica Annua, 48-49 (2001-02), págs. 115-155; Barrio Gozalo, El Clero en la España, págs. 186-191, ofrece una visión general del tema. 
neficio más productivo, dando lugar a movimientos migratorios, tanto de ámbito diocesano como extradiocesano ${ }^{52}$.

Por otra parte, el sistema beneficial se convirtió en uno de los elementos más negativos para los fines de la vida religiosa, del funcionamiento de las instituciones eclesiásticas y de la eficacia del gobierno episcopal. El interés económico anexo al beneficio no permitía, en muchos casos, un reclutamiento eclesiástico satisfactorio desde el punto de vista moral y cultural, con todas las consecuencias negativas que esto tenía para el ejercicio de la actividad pastoral y la vida religiosa de los fieles. Además, el desigual nivel económico de los beneficios provocaba grandes diferencias dentro del cuerpo clerical; es decir, mientras había beneficios dotados con una rica prebenda y sin ningún tipo de cargas, había otros con cura de almas privados de los recursos económicos necesarios.

Así mismo, la autoridad episcopal veía notablemente reducida su autoridad, tanto porque la mayor parte de los beneficios escapaban a su jurisdicción, al ser de patronato o de provisión pontificia, como porque sus titulares una vez que recibían la colación canónica lo ejercían con plena independencia del prelado. Por ello, la persistencia del sistema beneficial chocó con los esfuerzos reformadores, y hay que esperar al último tercio del siglo XVIII para que Carlos III impulse la reforma beneficial en las diócesis españolas, aunque las resistencias fueron tan grandes que no se concluyó hasta después de la firma del concordato de 1851, cuando ya había desaparecido la parte más importante de la renta de los beneficios por la abolición de la obligación civil de pagar los diezmos y la desamortización de sus bienes ${ }^{53}$.

En las últimas décadas han aparecidos artículos sobre la reforma beneficial de algunas diócesis o regiones, y yo publiqué un libro sobre El Sistema beneficial de la iglesia española, pero todavía falta mucho por hacer, porque la organización beneficial difiere de unas diócesis a otras, y la falta de estudios de ámbito diocesano o regional deja al descubierto muchos problemas de la historia eclesiástica española.

52 Maximiliano Barrio Gozalo, «El sistema beneficial en la España del siglo XVIII. Pervivencias y cambios», Cuadernos Dieciochistas, 32 (2001), págs. 73-107; y BARRIo Gozalo, El sistema beneficial de la iglesia española; Elena CATALÁn, «El derecho de patronatos y el régimen beneficial de la Iglesia española en la Edad Moderna, Hispania Sacra, 56 (2004), págs. 135-168; M. Teresa BENITo AguAdo, La sociedad vitoriana en el siglo XVII. El clero espectador y protagonista, Bilbao, Universidad del País Vasco, 2001, Arturo Morgado, «Provisión de beneficios eclesiásticos en la diócesis de Cádiz durante el Antiguo Régimen, 1700-1836», Crónica Nova, 18 (1990), págs. 343-363; etc.

53 Almudena García Herreros, La diócesis de Palencia al final del Antiguo Régimen (1752-1822): organización y reforma beneficial, Palencia, Diputación Provincial de Palencia, 2008; Manuel Martín Riego, «El plan de erección y dotación de curatos en 1791. Una reforma en la archidiócesis hispalense», Isidorianum, 4 (1993), págs. 199-245; José SARmiento, Reforma Beneficial en la diócesis de Badajoz durante la crisis del Antiguo Régimen (1769-1841), Badajoz, Diputación Provincial de Badajoz, 2005; M. a Auxiliadora SEviLLA PÉrez, Reforma beneficial en la diócesis de Zamora. Tesis doctoral. UNED, 1995; etc. 
En 1973 Domínguez Ortiz decía que la bibliografía sobre las órdenes religiosas era muy copiosa, pero que la mayoría no se podía utilizar para ofrecer una visión general del clero regular, máxime si se pretendía hacer una síntesis de carácter socio-económico ${ }^{54}$. Estas sugerencias en parte han sido atendidas y en parte siguen sin la respuesta adecuada ${ }^{55}$.

La investigación histórica sobre las órdenes religiosas cuenta con abundante documentación, tanto manuscrita como impresa, pero si no se utiliza con la metodología adecuada los resultados pueden ser nefastos, al presentar como comportamiento general lo que es algo excepcional. A pesar de esto, hay que recordar que, como consecuencia de la supresión de los monasterios y conventos, y la nacionalización de sus bienes (1835-1836), el gobierno se incautó de sus archivos. Pero, como a los desamortizadores les interesaba fundamentalmente la documentación de carácter económico (que se llevó a los archivos provinciales y luego a los nacionales), apenas prestaron atención a la de tipo social, cultural y religioso, que en buena parte se perdió o malvendió, como sucedió con los libros de profesiones, difuntos y visitas pastorales, lo que dificulta el estudio de los cambios sociales, familiares, culturales y los comportamientos ${ }^{56}$. Es vedad que en los archivos civiles e inquisitoriales se encuentran documentos de carácter procesal que permiten reconstruir algún aspecto de la vida conventual, pero generalmente informan de los aspectos negativos: abusos, pleitos, prohibiciones, trasgresiones o delitos de todo tipo. Y este tipo de fuente, usada por algunos estudiosos que se ocupan del clero regular y también del secular sin las matizaciones necesarias, ofrece una visión deformada de la realidad histórica, al presentar solo el lado oscuro de los comportamientos ${ }^{57}$.

Algo parecido sucede con la documentación de carácter hagiográfico que se ha trasmitido en fuentes manuscritas o impresas a través de las patentes de difuntos o cartas edificantes que se distribuían entre las familias religiosas. Es-

54 Domínguez Ortiz, Las clases privilegiada, págs. 273-274.

55 Teófanes Egido López, «Historiografía del clero regular en la España Moderna», en Antonio Cortés Peña y Miguel L. López-Guadalupe (eds), La iglesia española..., págs. 9-37, ofrece unas páginas sugestivas sobre el tema de los regulares.

56 Quizá esto explique que sean mucho más abundantes los estudios sobre la desamortización de los bienes de las comunidades religiosas que los estudios sobre la exclaustración, entre los que sigue siendo válida la ya clásica monografía de Manuel Revuelta, La Exclaustración (1833-1840), Madrid, BAC, 1976. La revista Memoria Ecclesiae, 6 y 7 (1995), está dedicada al estudio de los archivos monásticos y sus fondos.

57 Entre los muchos estudios que utilizan estas fuentes se pueden citar los de Stephen HaLICZER, Sexualidad en el confesionario. Un sacramento profanado, Madrid, Siglo XXI, 1998; Adelina Sarrión, Sexualidad y confesión, Madrid, Alianza, 1994; etc. 
tos escritos constituyen un género peculiar, que presentan al fraile o a la monja ejemplar con las mismas palabras, conceptos y virtudes ${ }^{58}$. Un problema similar podemos encontrar en las crónicas, que a veces dan tanto valor a lo imaginado como a lo acontecido 59 .

En el siglo XIX y en el XX se publicaron algunas historias sobre distintas familias religiosa de gran interés, aunque a veces están escritas con criterios clericales y cierto acento apologético ${ }^{60}$. No obstante, son obras de consulta necesaria, que algunos historiadores actuales han aprovechado, cuando no plagiado más o menos descaradamente.

En la segunda mitad del siglo xx, al igual que sucede en el clero secular, el estudio de las órdenes religiosas fue abandonando los tonos hagiográficos y apologéticos, y los planteamientos clericales, para convertirse en territorio de los historiadores profesionales. Y desde las últimas décadas del siglo pasado ha sido uno de los capítulos mejor atendidos. En buena parte gracias a los propios eclesiásticos, pero historiadores profesionales y profesores universitarios, empeñados en este quehacer, como Batllori, Beltrán de Heredia, Egido López, García Oro, Revuelta, Serra, Tellechea, etc., y, por supuesto, por los muchos profesores universitarios seglares que se interesan por la historia de las familias religiosas ${ }^{61}$. Gracias a estos y otros historiadores se ha avanzado mucho en el conocimiento de las órdenes religiosas. Entre los sectores más estudiados están las órdenes militares y las reformas observantes, descalzas o recoletas ${ }^{62}$. Y entre las órdenes nuevas, la mejor conocida desde planteamientos historiográficos serios es la Compañía de Jesús, aunque las demás órdenes también cuentan con

58 José L. SÁnchez Lora, Mujeres, conventos y formas de religiosidad en el Barroco, Madrid, FUE, 1988, lo ha expuesto en algunos trabajos; y Daniel VAQuerín APARICIO, Vida, espiritualidad y proyección social en los franciscanos descalzos en la España de la Ilustración, Tesis doctoral. Madrid, Universidad Complutense, 2005, lo hace para los descalzos franciscanos.

59 Para la referencia bibliográfica de las crónicas más importantes ver el trabajo de Magdalena de P. Pi Corrales et al., «Las órdenes religiosas en la España moderna, dimensiones de la investigación histórica», en Enrique Martínez y Vicente Suárez (dirs.), Iglesia y sociedad en el Antiguo Régimen, I, Las Palmas, Universidad de las Palmas, 1994, págs. 205-251; así como el proyecto de investigación que dirige Ángela ATIENZA sobre las monjas franciscanas.

60 Entre ellas cabe destacar las de Antonio Astrain, Historia de la Compañía de Jesús en la Asistencia de España, Madrid, Razón y Fe, 1857-1928, 7 vols.; Silverio de Santa Teresa, Historia del Carmen Descalzo en España, Portugal y América, Burgos, Monte Carmelo, 1935-1952, 15 vols.; Ernesto Zaragoza, Los generales de la Congregación de San Benito de Valladolid, Silos, Monasterio de Silos, 1973-1987; Balbino VeLasco, Los Carmelitas. Historia de la Orden del Carmen, IV. El Carmelo español, Madrid, BAC, 1993; etc.

61 A modo de ejemplo basta con citar la obra de Enrique MARTínEz RuIz et al., El peso de la Iglesia. Cuatro siglos de Órdenes religiosas en España, Madrid, Actas, 2004.

${ }^{62}$ José García Oro ha estudiado el capítulo de las reformas: La reforma de los religiosos españoles en tiempo de los Reyes Católicos, CSIC, Valladolid, 1969; y «Conventualismo y observancia, en Ricardo GarcíaVilloslada (dir.), Historia de la iglesia en España, Madrid, BAC, 1980, vol. III/1, págs. 211-349. 
buenas monografías. Entre los muchos aspectos que se han estudiado, en mi opinión, destacan tres: la fundación de los conventos, las bases económicas y el reformismo borbónico y los conventos.

Aunque contamos con muchos trabajos que analizan la fundación de un convento o de todos los de la orden religiosa ${ }^{63}$, así como de los se establecen en una localidad, comarca o diócesis ${ }^{64}$, escasean las síntesis que ofrezcan una visión general del hecho fundacional. No obstante, contamos con algunos estudios que han afrontado este objetivo desde el punto de vista de la historia social y del poder, y trazan la geografía conventual y la cronología de su expansión en la España moderna ${ }^{65}$. La mayoría de los conventos se fundan en los primeros siglos modernos, luego se produce una parálisis fundacional por la pérdida de estimación que sufre el clero regular en el siglo XVIII, de tal manera que si en el siglo XVI se fundan más de mil conventos, y en el XVII se acercan a los novecientos, en el XVIII apenas llegan a los ciento cuarenta.

El ímpetu expansivo se ve facilitado por los grupos sociales que promueven, patrocinan, apoyan o financian las nuevas fundaciones, pues el modelo religioso tridentino genera el clima propicio para que la fundación o dotación de un convento se considere como una de las acciones más meritorias para conseguir la salvación eterna y el reconocimiento social, de forma que las consideraciones sociales y religiosas se mezclan estrechamente. Aunque las órdenes religiosas tienen la iniciativa en buena parte de las fundaciones, en la mayoría de los casos se halla detrás el apoyo de alguna familia o institución, ya sean miembros de la familia real, de la nobleza, de las oligarquías urbanas, del clero secular o de las instituciones municipales. Por otra parte, aunque el clero regular se siente más atraído por la ciudad que por el campo, y ello explica su elevada concentración de los núcleos urbanos más importantes, no hay que olvi-

${ }^{63}$ Balbino Velasco, Historia del Carmelo Español, III, Roma, Institutum Carmelitanum, 1993; J. A. Echevarría, «Los franciscanos capuchinos de la Península Ibérica en los siglos XVIII y XIX», en M. a del Mar Graña Cid (ed.), El franciscanismo en la Península Ibérica. Balance y perspectivas, Barcelona, Estudios Franciscanos, 2005, págs. 319-348; Albert GonzÁlez Caballero (coord.), Los capuchinos en la Península Ibérica, 400 años de historia (158-1978), Sevilla, GBG Editores, 1985; Ángel MarTínez Cuesta, Historia de los Agustinos Recoletos, I. Desde los orígenes hasta el siglo XIX, Madrid, Ed. Augustinus, 1995; etc.

64 Maximiliano Barrio Gozalo, Segovia, ciudad conventual. El clero regular al final del Antiguo Régimen (1768-1836), Valladolid, Universidad de Valladolid, 1995, y Maximiliano Barrio Gozalo, Religión y sociedad en Valladolid y su Obispado (1595-1851), Valladolid, Universidad de Valladolid, 2016; José J. Barranquedo, Conventos de la provincia de Ciudad Real, Ciudad Real, Diputación Provincial, 2003.

65 Ángel Atıenza, Tiempo de conventos. Una historia social de las fundaciones en la España Moderna, Madrid, Marcial Pons, 2008; y Ángel ATIEnZA, «Nuevas consideraciones sobre la geografía y la presencia conventual en la España Moderna«, Hispania Sacra, 61 (2009), págs. 51-75; Barrio Gozalo, El Clero en la España Moderna, págs. 323-356; Juliana Beldad Corral, Conventos y monasterios en los dominios de las Órdenes Militares de la meseta sur castellana en la Edad Moderna. Tesis doctoral inédita, Universidad de Valladolid, 2006; etc. 
dar que la dispersión fue también una realidad constitutiva del mapa conventual español de la modernidad.

El estudio de las economías del clero regular tiene una larga tradición bibliográfica, sobre todo desde los años noventa del siglo pasado, en que se han abordado cuestiones fundamentales, que han completado los estudios realizados por la historiografía anterior ${ }^{66}$. Muchos de los estudios que han aparecido en las últimas décadas lo han hecho en revistas y obras colectivas, como en las actas de los congresos de Historia Económica que han dedicado alguna sección al estudio de las economías monásticas, y también en las publicaciones de los grupos de investigación que se ocupan del estudio de los regulares ${ }^{67}$. Aunque este tipo de trabajos se reparten a lo largo y ancho de toda la Península, quizá donde se han realizado de forma más sistemática, al menos por lo que se refiere a los monasterios, es en Galicia, donde, además de extensas propiedades, tenían un importante señorío, según ha puesto de manifiesto María Seijas hace unos años ${ }^{68}$.

Por último, uno de los temas que ha merecido gran atención de los historiadores ha sido el referente al reformismo borbónico y las órdenes religiosas, posiblemente por la seducción ejercida por el tema de la expulsión de los jesuitas, objeto de numerosísimas contribuciones, pero no hay que olvidar que la reforma también afectó a las demás órdenes religiosas. Es decir, el regalismo borbónico retoma, desde comienzos del siglo, las preocupaciones de los siglos

66 Entre los trabajos anteriores a la década de los noventa destacan, entre otros, las obras de Enrique Llopis Agelán, Las economías monásticas al final del Antiguo Régimen en Extremadura, Madrid, Universidad Complutenses, 1980. Tesis doctoral; Pedro García Martín, El Monasterio de San Benito el Real de Sahagún en la época moderna, Valladolid, Junta de Castilla y León, 1985; Concepción Burgo López, Un dominio monástico femenino en la Edad Moderna. El monasterio benedictino de San Paio de Antealtares, Santiago de Compostela, Universidad de Santiago, 1986; Daniel González PAZ, El monasterio de Santa María de Villanueva de Oscos. De la Reforma a la Exclaustración, Oviedo, Universidad de Oviedo, 1989. Posteriores a los noventa son las obras de José M. López García, La transición del feudalismo al capitalismo en un señorío monástico castellano: el Abadengo de la Santa Espina (1147-1835), Valladolid, Junta de Castilla y León, 1990; Antonio L. López Martínez, La economía de las órdenes religiosas en el Antiguo Régimen. Sus propiedades y rentas en el Reino de Sevilla, Sevilla, Diputación Provincial de Sevilla, 1992; José A. Sebastián Amarilla, Agricultura y rentas monásticas en tierras de León. Santa María de Sandoval (1167-1835), Madrid, Universidad Complutense, 1992; Ángela ATIENZA, Propiedad, explotación y rentas: el clero regular zaragozano en el siglo XVIII, Zaragoza, Diputación de Aragón, 1993; etc.

${ }_{67}$ Entre las muchas publicaciones de este tipo, me limito a citar las de Ofelia Rey Castelao, «Las economías eclesiásticas en la Edad Moderna: un estado de la cuestión de la historiografía reciente (19942006)», en Antonio Cortés Peña y Miguel L. López-Guadalupe (eds.), La Iglesia española, págs. 179-222, y «Las economías monásticas femeninas. Un estado de la cuestión», en Cristina Borderías (coord.), La historia de las mujeres: perspectivas actuales, Barcelona, AEIHM, 2009, págs. 197-224; etc. Fiorenzo LaNDI (ed.), Accumulation and dissolution of large estates of the regular clergy in Early Modern Europe, Rimini, Guaraldi, 1999; Martínez Ruiz (dir.), El peso de la Iglesia, 2004; etc.

68 María Seijas Montero, «Balance económico de los monasterios cistercienses del Sudoeste gallego a fines del Antiguo Régimen», Obradoiro, 19 (2010), págs. 331-359. 
anteriores por el excesivo número de conventos y de sus moradores, así como por las grandes propiedades que algunos detentan. Pero, en este siglo hay mayor voluntad política para llevar a cabo la reforma y un mayor respaldo social, por la desafección política y social que afectó a los regulares, sobre todo, en la segunda mitad del siglo. Pues en la mirada crítica y en su respaldo social no solo participan las elites gubernamentales, sino también sectores de la aristocracia y de las oligarquías, miembros del clero secular e, incluso, algunos representantes del regular, conscientes de los problemas y de la necesidad de llevar a cabo reformas en sus institutos.

Aunque los deseos e intentos por sujetar al control regio a los regulares no es algo nuevo, ni tampoco la política de reformas, será en el reinado de Fernando VI cuando nos encontremos ante el inicio de la escalada reformista del clero regular ${ }^{69}$. Pero mientras los ilustrados se conforman con reformar a la mayoría de los regulares, en el caso de los jesuitas optan por la expulsión y posterior extinción, porque la Compañía representa la encarnación del espíritu obstinadamente conservador que los ilustrados combaten en la Iglesia, cuya expulsión y posterior supresión ha dado lugar a múltiples estudios ${ }^{70}$. En segundo lugar, se critica el excesivo número de religiosos, pues los frailes, a juicio de Grimaldi, «son infinitos, les convine la independencia y el desorden. Llaman hereje al que procura el remedio y, como tienen ganado al vulgo y a los entendimientos débiles, vencen al fin y aun escarmientan a los bien intencionados» ${ }^{71}$.

El excesivo número de religiosos que habitaba algunos conventos provocaba un desequilibrio entre la renta disponible y el número de frailes que había que mantener, lo que obligaba a que algunos tengan que salir fuera del convento para buscar alimento para sí y para la comunidad, lo que dio lugar a que «multitud de religiosos» vivieran fuera del convento. Para evitar este problema, desde 1750, se ordenó su reintegro al convento, aunque con poco éxito, y en 1764 se pidió a los obispos que informasen del número de religiosos de cada convento, sus rentas y estilo. La respuesta de los prelados confirmó, en el caso de los mendicantes, lo que ya se suponía: número excesivo de frailes, imposibilidad de

69 Enrique Giménez LóPEZ y Mario Martínez Gomis, «El episcopado español y la encuesta del marqués de la Ensenada de 1750», en Emilio La Parra y Jesús Pradells (eds.), Iglesia, Sociedad y Estado en España, Francia e Italia (ss. XVIII-XIX), Alicante, Instituto Juan Gil-Albert, 1991, págs. 292.

70 La bibliografía sobre la expulsión de los jesuitas es inmensa. Una muestra bibliográfica significativa se encuentra en la selección preparada por Librería Polifemo bajo el título «Jesuitas. Religión, política y educación» con motivo de la celebración en Madrid, en junio de 2011, del Congreso Internacional Los Jesuitas: Religión, Política y Educación (ss. XVI-XVIII). Está disponible en la dirección electrónica http://www.polifemo. com/Jesuitas.pdf.

${ }^{71}$ Archivo General de Simancas (AGS), Estado. Grimaldi a Tanucci. Aranjuez, 9 de junio de 1767. 
mantenerse con sus rentas y limosnas, y quiebra de la vida religiosa ${ }^{72}$. Por fin, en los primeros años del de la década del setenta la reforma dio un paso importante con la con la reducción de los agustinos recoletos, carmelitas descalzos, mercedarios calzados y descalzos, y trinitarios descalzos ${ }^{73}$.

Normalmente se ha destacado la moderación de la política ilustrada respecto a la reforma de los regulares y a la amortización de sus tierras, a pesar de que Grimaldi se queje de que «la langosta de frailes se había cargado con todas las mejores haciendas» ${ }^{74}$. Sin embargo hay que valorar la trascendencia de algunas medidas y la repercusión que tuvieron en la situación de los religiosos, socavando las bases sobre las que se asentaba su poder, limitando su presencia en la vida social y restringiendo su influencia. Además, la generalización de las críticas e incentivas contra los regulares fue preparando el clima que, años más tarde, hizo posible la exclaustración.

Por último, por lo que respecta a la historiografía sobre las monjas, se puede afirmar que ha avanzado a pasos agigantados en las últimas décadas; en buena parte, como consecuencia de la importancia que ha cobrado la historia de las mujeres y de género, así como el desarrollo del feminismo. Desde que se celebraron los congresos sobre el monacato femenino en 1992, 1994, 2003, 2005 , etc., se hayan multiplicado los estudios y hoy se conocen mejor muchos aspectos de la vida de las monjas ${ }^{75}$. Algunos, como la fundación y dotación de los conventos y la evolución de sus moradoras, así como las bases económicas

72 Maximiliano Barrio Gozalo, «Política eclesiástica y religión a través de la correspondencia de Tanucci y Grimaldi a mediados del siglo XVII», Anthologica Annua, 40 (1993), págs. 215-245, y Maximiliano BARrio Gozalo, «El clero regular en la España de mediados del siglo XVIII a través de la encuesta de 1764», Hispania Sacra, 47 (1995), págs. 121-169.

73 Antonio L. Contés Peña, La política religiosa de Carlos III y las órdenes mendicantes, Granada, Universidad de Granada, 1989; Gloria Á. Franco Rubio, «Algunas anotaciones sobre la reforma del clero regular bajo el reinado de Carlos III: los mercedarios calzados», en VV. AA., Carlos III y su siglo, vol. II, págs. 569-599; Maximiliano Barrio Gózalo, «Reforma y supresión de los regulares al final del Antiguo Régimen», Investigaciones Históricas, 20 (2000), págs. 89-118; Ceferino CARO LóPEZ, «La reducción de las órdenes regulares. Documentos para un caso de política religiosa en tiempos de Carlos III», Hispania Sacra, 44 (1992), págs. 335-392; etc.

74 AGS, Estado, leg. 6096. Grimaldi a Tanucci. San Ildefonso, 25 de septiembre de 1764; Francisco Tomás y Valiente, El marco político de la desamortización en España, Barcelona, Ariel, 1972, y, sobre todo, su prólogo a la edición de Pedro Rodríguez de Campomanes, Tratado de la regalía de la amortización, Madrid, Ediciones Revista del Trabajo, 1975.

75 M. ${ }^{a}$ Isabel Viforcos y Jesús Paniagua (coords.), El monacato femenino en España, Portugal y América. Actas del Congreso Internacional, León, Universidad de León, 1993. 2 vols.; Manuel Ramos Medina y Josefina Muriel, Memoria del II congreso Internacional: el monacato femenino en el Imperio español. Monasterios, beaterios, recogimientos y colegios, México, CONDUMEX, 1995; Francisco J. CAmpos y FernándEZ DE Sevilla (coords.), La clausura femenina en España, San Lorenzo de El Escorial, R.C.U. Escorial, 2004; M. ${ }^{a}$ Isabel Viforcos y M. ${ }^{a}$ Dolores Campos (coords.), Fundadores, fundaciones y espacios de vida conventual: nuevas aportaciones al monacato femenino, León, Universidad de León, 2005, etc. 
y su forma de administración, son los que más se han estudiado ${ }^{76}$, mientras que los referentes al importe de la dote, sociología de las monjas, el servicio doméstico y, sobre todo, la clausura, la vida en común, la forma de vida y la ocupación de las monjas necesitan más atención por ser aspectos mal estudiados o mal interpretados ${ }^{77}$.

\section{Balance y perspectivas}

A pesar de los muchos estudios que se han publicado sobre el clero en las últimas décadas, todavía hay muchos aspectos pendientes que completar:

En primer lugar, al estudiar el estamento eclesiástico hay que tener en cuenta que el clero secular es un grupo heterogéneo y el regular no es el grupo monolítico como algunos estudiosos han querido presentarlo. Es verdad que las proyecciones historiográficas de las últimas décadas recalcan los diversos mundos del clero, como un espejo en el que se refleja la sociedad de su tiempo. No obstante hay que profundizar en la conflictividad que se da en el clero. En el secular los enfrentamientos o los roces se producen entre el clero parroquial, los cabildos catedralicios y los obispos, tanto por motivos económicos como jurisdiccionales o de comportamientos. Y esto explica que las asociaciones de clérigos (Universidades de beneficiados, Cabildos de curas y beneficiados, etc.) funcionen las más de las veces como instituciones para defender los derechos e

${ }^{76}$ Baudilio BARreIRo, «El monacato femenino en la Edad Moderna: demografía y estructura social», en M. ${ }^{a}$ Isabel Viforcos y M. ${ }^{a}$ Dolores Campos, El mocato femenino en España, vol. II, págs. 57-74; M. ${ }^{a}$ Concepción Burgo LóPEZ, «Política económica y gestión administrativa en las entidades monásticas femeninas»,

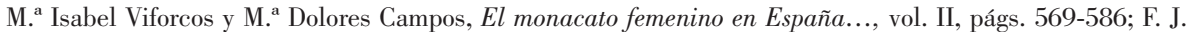
Campos y Fernández de Sevilla, «El monacato femenino de la España de la Ilustración en cifras», en F. J. Campos y Fernández de Sevilla (coord.), La clausura femenina en España, vol. I, págs. 7-82; M. a del Carmen GómEz García, «Trabajo y actividades de las religiosas en los conventos malagueños (siglos XVI-XVII)», en M. J. Vara y Virginia Maquieira (coords.), El trabajo de las mujeres, siglos XVI-XX, Madrid, Universidad Autónoma de Madrid, 1996, págs. 107-116; Ofelia Rey Castelao, «Las economías monásticas femeninas: un estado de la cuestión», en Cristina Borderías (ed.), La historia de las mujeres, perspectivas actuales, págs. 197-224; Jesús Pérez Morera, «La república del claustro: jerarquía y estratos sociales en los conventos femeninos», Anuario de Estudios Atlánticos, 51 (2005), págs. 327-389; etc.

77 Juliana BeLdad Corral, «La clausura en los conventos rurales femeninos de La Mancha en los siglos XVI y XVII», en F. J. Campos y Fernández de Sevilla (coord.), La clausura femenina, vol. I, págs. 319-340; Manuel DE CASTRO, «Los monasterios de concepcionistas franciscanas en España», Archivo Ibero-Americano, 203/4 (1991), págs. 411-477; Eduardo Montagut Contreras, «Servicio doméstico y educación en los conventos femeninos del Antiguo Régimen, siglo XVIII», Torre de los Lujanes, 15 (1990) págs. 156-168; Ofelia REY Castelao, «El servicio doméstico del clero regular gallego a fines de la Edad Moderna», en Raquel Casal et al. (eds.), Galicia Monástica. Santiago de Compostela, Universidad de Santiago, 2009, págs. 289-310; Concha TorRes SÁnchez, La clausura imposible: conventualismo femenino y expansión contrarreformista, Madrid, Asociación cultural Al-Mudaya, 2000; etc. 
intereses del bajo clero. La conflictividad también se da entre el clero secular y el regular, casi siempre por cuestión de diezmos y derechos de estola, así como entre las distintas órdenes religiosas por motivos de precedencia y, sobre todo, de escuela, sin que falten los enfrentamientos entre las distintas facciones de una misma orden o de un monasterio con motivo de las elecciones ${ }^{78}$.

En segundo lugar, conocemos bastante bien los aspectos socio-culturales y económicos de los obispos y canónigos, pero no sucede lo mismo con los miembros del clero parroquial. Sabemos algo de los aspectos institucionales, pero muy poco de su estilo de vida y labor pastoral, porque las fuentes que más se utilizan, como las visitas pastorales y la documentación procesal, ofrecen una imagen de los aspectos negativos o los que se debe corregir. Algo similar sucede con la institución parroquial, que desempeñó una importante función en la sociedad española de la época moderna. Pues, además de su función religiosa, constituyó un elemento de socialización, un espacio relacional que aglutinaba a grupos sociales y ayudaba a conformar una conciencia de pertenencia a una comunidad espiritual y social ${ }^{79}$.

En tercer lugar, para conocer la estructura del clero secular y, más aún del clero parroquial, sería conveniente hacer un mapa de la organización beneficial de las distintas diócesis o regiones españolas, pues esto permitiría conocer las peculiaridades del clero diocesano en los distintos obispados.

En cuarto lugar, se conoce mejor por los historiadores profesionales la vida externa de los monasterios y conventos que la interna; es decir, la vida regulada por las constituciones, ceremoniales, usos y costumbres, tan importante en la vida conventual, ha sido poco estudiada y es diferente de unas órdenes a otras. Pues, como decía García Colombás, han proliferado los trabajos sobre las economías monásticas, pero se ha olvidado que lo esencial es la dimensión religiosa ${ }^{80}$. De todas formas, yo creo que este aspecto, como sucede en el clero secular, ha sido más atendido por los historiadores que son eclesiásticos y conocen mejor el mundo de la vida religiosa y ministerial.

En quinto lugar, la historiografía sobre las monjas ha avanzado a pasos agigantados en las últimas décadas. Pero, como dice Ofelia Rey, la floración bibliográfica que se ha ocupado de las religiosas en los últimos años no significa

78 Maximiliano Barrio Gozalo, «Las órdenes religiosas y el confesor real en España a mediados del siglo XVII», Cheiron, 43-44 (2005), págs. 371-396, analiza la conflictividad interna de los regulares y la conflictividad entre las distintas órdenes religiosas y con otras instituciones

79 Puigvert, Església, territorio i sociabilitat, 2001; SAAVEDra et al., «La red parroquial y el clero rural en la Galicia», págs. 93-128; etc.

80 García M. CoLombás, «Apuntes para la historia de la espiritualidad monástica en el noroeste español», en VV. AA., XV Centenario del nacimiento de san Benito, Oviedo, Monasterio de San Pelayo, 1982, págs. 619-634. 
que esté todo dicho sobre este colectivo, pues se trata de una bibliografía muy desigual, efecto en gran medida de la celebración de centenarios de órdenes y fundaciones, y directamente influida por la historia de las mujeres, que ha encontrado en los conventos femeninos un filón documental, frente a la carencia de escritos de las demás mujeres, a pesar de que la información conservada sobre los conventos sea parcial por la pérdida de la documentación en los procesos desamortizadores ${ }^{81}$.

Por último, la historiografía sobre el clero ha dado pasos de gigante en las últimas décadas, pero todavía falta mucho por hacer. No obstante, sería conveniente que los estudiosos no olviden los enfoques eclesiásticos del problema y no se limiten a considerar a los hombres de la Iglesia como meros componentes de los grupos privilegiados.

Para terminar diré que, cuando empecé a investigar, en la década de los setenta, algunos profesores universitarios miraban despectivamente el estudio de la historia de la Iglesia, como cosa de curas y frailes. En cambio, desde hace ya varias décadas, los estudios sobre el clero se han equiparado y, en algunos casos, superado a los de otros grupos sociales, como la nobleza. Y esto se puede constatar consultado los proyectos de investigación subvencionados por el Ministerio y las Autonomías, las tesis doctorales que se defienden y los artículos que se publican en las Revistas de Historia de las Universidades y Centros de Investigación, por no citar las propias de las instituciones eclesiásticas.

81 Magdalena de P. Pi Corrales et al., «Las órdenes religiosas en la España moderna: dimensiones de la investigación histórica», en Enrique Martínez Ruiz y Vicente Suárez Grimón (eds.), Iglesia y sociedad en el Antiguo Régimen. Las Palmas, Universidad de Las Palmas, 1994, págs. 205-252; Marion Reder Gadow, «Las voces silenciosas de los claustros de clausura», Cuadernos de Historia Moderna, 25 (2000), págs. 279-338; Rey Castelao, «Las economías monásticas femeninas», págs. 197-224; etc. 